\title{
Pengembangan Model Pembelajaran Matematika Realistik Indonesia tentang Perbandingan di Kelas VII SMP
}

\author{
Husnul Laili \\ Dosen STIT Palapa Nusantara \\ Husnullaili29@gmail.com
}

\begin{abstract}
This study aims to develop a valid, practical, and effective Indonesian realistic mathematics learning model for proportions. The development of the learning kit in this study employed the model by Plump that had been modified by the product quality by Nieveen. The development of the model consisted of the preliminary investigation, design, and evaluation. The dissemination stage was not implemented in this study. The research instruments consisted of: (1) instrument evaluation sheets; (2) validation sheets; (3) learning management observation sheets; (4) student and teacher activity observation sheets; (5) student response questionnaires; and (6) learning achievement tests.

Through a development process, this study produced: (1) an Indonesian realistic mathematics learning model book; (2) Indonesian realistic mathematics learning kits; and (3) research instruments. The effectiveness of the realistic mathematics learning model on the basis of: (1) the percentage of the attainment of the students' learning mastery classically with the moderate and high mastery levels being $80 \%$ of 35 students sitting for the test; (2) the percentage of the attainment of the ideal time limit for each category of student and teacher activities; (3) the average score of the category of teachers' ability to manage learning which was 3.54, in the moderate category; and (4) the students' positive responses to learning components and activities.
\end{abstract}

Keyword : realistic mathematics learning model for proportions

\section{PENDAHULUAN}

Menurut Freudenthal pengembangan RME (Realistic Mathematics Education) didasarkan pada dua pandangan, yaitu matematika harus dikaitkan dengan hal yang nyata bagi murid dan harus dipandang sebagai aktivitas manusia. Matematika sebagai aktivitas manusia, berarti manusia harus diberikan kesempatan untuk "menemukan kembali" ide dan konsep matematika dengan 
bimbingan orang dewasa. Pandangan "menemukan kembali”, berarti siswa diberi kesempatan menemukan sendiri konsep matematika dengan menyelesaikan berbagai soal kontekstual. Berdasarkan soal kontekstual tersebut siswa membangun model dari (model of situation) situasi soal, kemudian menyusun model matematika untuk (model for formal mathemation) menyelesaikan hingga mendapatkan pengetahuan formal matematika. ${ }^{1}$

Pembelajaran akan lebih bermakna dan relevan apabila masalah yang diberikan adalah masalah-masalah kontekstual dan realistik, yaitu masalah yang sudah dikenal dan dekat dengan kehidupan siswa. Dengan demikian, masalah kontekstual dapat digunakan sebagai titik awal dalam pembelajaran matematika untuk membantu siswa mengembangkan pengertian terhadap konsep matematika yang dipelajari, menyusun strategi, dan menemukan sifat-sifat dalam matematika. Konsep matematika yang muncul dari masalah kontekstual merupakan salah satu ciri dari matematika realistik. $^{2}$

Berdasarkan uraian di atas, dapat ditarik sebuah kesimpulan bahwa matematika realistik adalah sebuah pendekatan yang mempunyai peluang untuk diterapkan dalam upaya perbaikan mutu pendidikan matematika di Indonesia dan untuk meningkatkan kualitas pembelajaran matematika di kelas perlu dikembangkan model pembelajaran matematika realistik Indonesia. Konsep matematika realistik yang dimaksud disini adalah matematika yang terkait dengan realitas dan lingkungan siswa. Masalah-masalah sehari-hari dapat digunakan sebagai sumber untuk memunculkan konsep, algoritma, atau sifat-sifat dalam matematika. Jadi pembelajaran tidak dimulai dengan definisi, teorema, dan diikuti contoh-contoh, tetapi siswa diajak untuk menemukan kembali konsep atau rumus melalui masalah-masalah riil.

\footnotetext{
${ }^{1}$ Gravemeijer, K. P. E. Developing realistics mathematics education. (Utrecht: CD $\beta$ Press, 1994). Hal. 1

${ }^{2}$ Masykur, Moch. \& Halim Fathani, Abdul. (2007). Mathematical intelligence cara cerdas melatih otak dan menanggulangi kesulitan belajar. (Yogyakarta: Ar-ruzz Media, 2008). Hal. 60
} 
Berdasarkan hasil pengamatan di SMP Negeri 1 Batukliang, siswa masih kurang aktif dalam pembelajaran matematika. Hal ini dapat dilihat dari respons siswa terhadap pertanyaan yang diajukan oleh guru, yaitu siswa kurang berani mengemukakan pendapat ataupun bertanya kepada guru. Dalam pembelajaran matematika tidak terjadi interaksi antara guru dan siswa maupun antarsiswa, sehingga pembelajaran lebih cenderung berpusat kepada guru dan siswa kurang memahami materi yang diajarkan. Hal ini mengakibatkan rata-rata nilai siswa pada mata pelajaran matematika masih di bawah standar ketuntasan belajar. Data hasil Ujian Nasional 2016/2017 di SMP Negeri 1 Batukliang Lombok Tengah menunjukkan bahwa dari 153 peserta Ujian Nasional hanya 72 orang siswa atau $47,05 \%$ yang tuntas belajar matematika (memperoleh nilai minimal 65).

\section{Pembelajaran Matematika Realistik Indonesia}

Realistic Mathematics Education (RME) di Indonesia dikenal dengan istilah Pendidikan Matematika Realistik Indonesia (PMRI) yang secara operasional disebut Pembelajaran Matematika Realistik Indonesia. yang dimaksud dengan "realistik" adalah pembelajaran matematika yang dikaitkan dengan "dunia nyata siswa" dan dapat dibayangkan oleh siswa. Masalah yang mengandung situasi "dunia nyata siswa" disebut masalah kontekstual. ${ }^{3}$ Selain itu Sutarto Hadi menyatakan bahwa masalah kontekstual dapat digali dari (1) situasi personal siswa, yaitu yang berkenaan dengan kehidupan sehari-hari siswa, (2) situasi sekolah/akademik, yaitu berkaitan dengan kehidupan akademik di sekolah dan kegiatan-kegiatan dalam proses pembelajaran siswa, (3) situasi masyarakat, yaitu yang berkaitan dengan kehidupan dan aktivitas masyarakat sekitar siswa tinggal, dan (4) situasi saintifik/matematik, yaitu yang berkenaan dengan sains atau matematika itu sendiri.

\footnotetext{
${ }^{3}$ Suryanto. \& Sugiman. (2006). Metode pembelajaran dimulai dengan pengenalan situasi riil. Diambil pada tanggal 16 Oktober 2006, dari http://www.kompas.com/kompascetak/0610/16jogja/29886.htm. hal.111
} 
Freudenthal mengungkapkan bahwa "Realistic mathematics education is rooted in Freudenthal's interpretation of mathematics as an activity". "Ungkapan tersebut menunjukkan bahwa pembelajaran matematika realistik adalah matematika sebagai aktivitas manusia, meliputi aktivitas pemecahan masalah, mencari masalah, dan mengorganisasi pokok persoalan, kemudian aktivitasaktivitas tersebut dinamakan matematisasi.

Terkait dengan aktivitas matematisasi dalam belajar matematika, Freudenthal menyebutkan dua jenis matematisasi, yaitu matematisasi horizontal dan vertikal dengan penjelasan sebagai berikut "Horizontal mathematization involves going from the world of life into the world of symbol, while vertical mathematization means moving within the world of symbol", . Pernyataan tersebut menjelaskan bahwa matematisasi horizontal meliputi proses transformasi masalah nyata/sehari-hari ke dalam bentuk simbol, sedangkan matematisasi vertikal merupakan proses yang terjadi dalam lingkup simbol matematika itu sendiri.

\section{Prinsip dan Karateristik Pembelajaran Matematika Realistik Indonesia}

Ada beberapa prinsip kunci dalam pembelajaran matematika realistik, yaitu: Pertama, Guided reinvention and progressive mathematizing (menemukan kembali secara terbimbing melalui matematisasi progresif) berdasarkan prinsip reinvention, para siswa semestinya diberi kesempatan untuk mengalami proses yang sama dengan proses saat matematika ditemukan. Sejarah matematika dapat dijadikan sebagai sumber inspirasi dalam merancang materi pelajaran. Selain itu, prinsip reinvention dapat pula dikembangkan berdasar prosedur penyelesaian informal. Dalam hal ini, strategi informal dapat dipahami untuk mengantisipasi prosedur penyelesaian formal. Untuk keperluan tersebut maka perlu ditemukan masalah kontekstual yang dapat menyediakan beragam prosedur penyelesaian serta mengindikasikan rute pembelajaran yang berangkat dari tingkat belajar

\footnotetext{
${ }^{4}$ Ibid... Gravemeijer, K. P. E. hal. 82

Van den Heuvel - Panhuizen, M. Assesment and realistic mathematics education.(Utrecht:Freudental Institut.1996).hal.11
} 
matematika secara nyata ke tingkat belajar matematika secara formal (progressive mathematizing).

Kedua, Didactical phenomenology (Fenomena didaktis), berdasarkan prinsip ini penyajian topik-topik matematika yang termuat dalam pembelajaran matematika realistik disajikan atas dua pertimbangan, yaitu memunculkan ragam aplikasi yang harus diantisipasi dalam proses pembelajaran dan kesesuaiannya sebagai hal yang berpengaruh dalam proses progressive mathematizing.

Ketiga, Self-developed models (Pengembangan model sendiri), berdasarkan prinsip ini saat mengerjakan masalah kontekstual siswa diberi kesempatan untuk mengembangkan model mereka sendiri yang berfungsi untuk menjembatani jurang antara pengetahuan informal dan matematika formal. Pada tahap awal, siswa mengembangkan model yang diakrabinya. Selanjutnya, melalui generalisasi dan pemformalan akhirnya model tersebut menjadi sesuatu yang sungguhsungguh ada yang dimiliki siswa. Tahapan tersebut dapat digambarkan pada Gambar berikut. ${ }^{6}$

\section{Gambar}

I

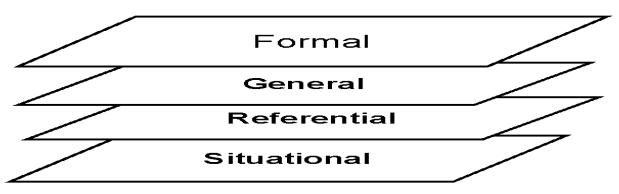

Tingkatan Model Pendidikan Matematika Realistik ${ }^{7}$

Berdasarkan gambar di atas, bahwa dalam pembelajaran matematika realistik terdapat empat tingkatan yaitu situations (situasi), model of (model dari), model for (model untuk), formal mathematics (matematika formal). Tingkatan pertama, berhubungan dengan aktivitas dalam kehidupan nyata. Dalam hal ini, siswa dikonfrontasikan dengan masalah kontekstual yang realistik. Tingkatan kedua, siswa mengembangkan model dari situasi masalah tersebut. Tingkatan ketiga, model dari situasi masalah tersebut berkembang menjadi model untuk

\footnotetext{
${ }^{6}$ Ibid, Gravemeijer...hal.90-91

${ }^{7}$ Ibid, Gravemeijer, hal.102
} 
pengetahuan formal matematika, pada tahap ini siswa tidak lagi berpikir terhadap situasi masalah melainkan sudah menggunakan representasi dengan simbol seperti angka, tanda bagi atau tanda kali dan sebagainya.

Tahapan model of dan model for merupakan kontribusi siswa terhadap proses pembelajaran yaitu penggunaan hasil dan konstruksi siswa sendiri. Selanjutnya, proses pembelajaran berlangsung secara interaktif antara siswa dan guru, serta siswa dan siswa. Pada tahap ini siswa dibimbing untuk mencapai pengetahuan matematika secara formal berupa algoritma, prosedur konvensional, notasi-notasi dan sebagainya. Dalam pembelajaran matematika realistik terdapat pendekatan secara holistik, di mana penerapan matematika sesungguhnya dilakukan secara terintegrasi antara bagian-bagian matematika itu sendiri maupun terintegrasi dengan bidang ilmu lain.

Ada beberapa karakteristik dari pembelajaran matematika realistik, yaitu sebagai berikut. Pertama, Penggunaan konteks, yaitu pembelajaran diawali dengan menggunakan masalah kontekstual. Masalah kontekstual yang diangkat sebagai awal pembelajaran harus masalah yang dikenali siswa. Kedua, Penggunaan model, yaitu sewaktu mengerjakan masalah kontekstual, siswa menggunakan model-model yang mereka kembangkan sendiri sebagai jembatan antara level pemahaman yang satu ke level pemahaman yang lain.

Ketiga, Penggunaan kontribusi siswa, yaitu kontribusi yang besar dalam proses pembelajaran diharapkan datang dari konstruksi dan produksi siswa sendiri yang mengarahkan mereka dari metode informal ke arah yang lebih formal. Dari hasil konstruksi dan produksinya diharapkan siswa termotivasi untuk melakukan refleksi pada bagian yang mereka sendiri anggap penting dalam proses pembelajaran, dan terakhir Interaktivitas antara siswa yang satu dengan siswa yang lain, juga antara siswa dengan pembimbing (guru) merupakan hal yang penting dalam pembelajaran konstruktif. Guru harus memberikan kesempatan kepada siswa untuk mengkomunikasikan ide-ide yang berupa proses dan hasil konstruksi mereka sendiri melalui pembelajaran yang interaktif, seperti diskusi 
kelompok, kerja kelompok, maupun diskusi kelas. Melalui interaktivitas seperti ini, setiap siswa diharapkan mendapat manfaat yang positif. ${ }^{8}$

Terdapat keterkaitan diantara berbagai bagian dari materi pembelajaran, yaitu struktur dan konsep matematika. Dalam pembahasan suatu topik biasanya memuat beberapa konsep yang berkaitan. Oleh karena itu, keterkaitan antartopik harus dieksploitasi untuk mendukung proses pembelajaran yang lebih bermakna.

\section{Sintaks Pembelajaran Matematika Realistik Indonesia}

Berdasarkan prinsip dan karakteristik Pembelajaran Matematika Realistik Indonesia (PMRI) serta memperhatikan pendapat tentang proses pembelajaran matematika dengan pendekatan PMRI di atas, maka disusun sintaks pembelajaran matematika realistik Indonesia ini adalah sebagai berikut.

\section{Memahami Masalah Kontekstual.}

Guru memberikan masalah (soal) realistik dan meminta siswa untuk memahami masalah tersebut. Karakteristik pembelajaran matematika realistik yang tergolong dalam langkah ini adalah karakteristik pertama yaitu menggunakan masalah kontekstual (the use of context).

\section{Mendeskripsikan Masalah Kontekstual.}

Setelah siswa dapat memahami masalah kontekstual yang diberikan, siswa diberi kesempatan untuk mendeskripsikan masalah kontekstual dengan melakukan refleksi, interpretasi atau mengemukakan strategi pemecahan masalah kontekstual yang sesuai untuk menyelesaikan masalah tersebut. Karakteristik PMRI yang tergolong dalam langkah ini adalah karakteristik keempat yaitu adanya interaksi (interactivity) antara guru dan siswa.

\section{Menyelesaikan Masalah Kontekstual.}

Siswa secara individual atau kelompok menyelesaikan masalah realistik dengan cara mereka sendiri. Perbedaan dalam menyelesaikan soal menggunakan lembar kegiatan, tidak dipermasalahkan. Guru memotivasi siswa untuk menyelesaikan masalah dengan cara mereka sendiri dengan memberikan

\footnotetext{
${ }^{8}$ Ibid,.. Gravemeijer. Hal..114-115
} 
pertanyaan, petunjuk, dan saran, misalnya bagaimana kamu tahu itu, bagaimana caranya, dan mengapa kamu berpikir seperti itu.

Semua prinsip PMRI tergolong dalam langkah ini adalah penemuan kembali yang terbimbing dan matematisasi progresif, fenomena yang bersifat mendidik (didactical phenomenology), dan mengembangkan model sendiri. Karakteristik PMRI yang tergolong dalam langkah ini adalah karakteristik kedua menggunakan model.

\section{Membandingkan dan Mendiskusikan Jawaban.}

Guru menyediakan waktu dan kesempatan pada siswa untuk membandingkan dan mendiskusikan jawaban mereka secara berkelompok, kemudian membandingkan dan mendiskusikan pada diskusi kelas. Pada tahap ini, dapat digunakan siswa untuk berani mengemukakan pendapatnya, meskipun pendapat tersebut berbeda dengan lainnya. Karakteristik PMRI yang tergolong dalam langkah ini adalah karakteristik ketiga dan keempat, yaitu menggunakan kontribusi siswa dan terdapat interaksi antara siswa dengan siswa lainnya.

\section{Menyimpulkan.}

Berdasarkan hasil diskusi kelas, guru memberi kesempatan pada siswa untuk menarik kesimpulan suatu konsep atau prosedur yang terkait dengan masalah realistik yang diselesaikan. Karakteristik PMRI yang tergolong dalam langkah ini adalah adanya interaksi antara siswa dengan guru (pembimbing).

\section{METODE PENELITIAN}

Berdasarkan pertanyaan penelitian yang telah dikemukakan sebelumnya, maka penelitian ini merupakan penelitian pengembangan. Pengembangan didefinisikan sebagai suatu pengkajian sistematis terhadap pendesainan, pengembangan dan pengevaluasian program, proses dan produk pembelajaran yang harus memenuhi kriteria valid, praktis, dan efektif.

Model pengembangan yang digunakan dalam penelitian ini mengacu pada model Plomp dengan memperhatikan tiga aspek kualitas produk yang dikemukakan Nieveen. Modifikasi yang dilakukan terhadap model Plomp yaitu pada fase tes, evaluasi, dan revisi menjadi validasi, uji coba, dan revisi. Alasan 
modifikasi pada fase ini adalah menyesuaikan dengan prosedur penilaian kualitas produk yang dikemukakan Nieveen. Sedangkan pada fase implementasi tidak dilaksanakan dalam penelitian ini, karena capaian hasil penelitian pengembangan ini tidak langsung disebarluaskan untuk dipakai.

Alur pengembangan model pembelajaran yang dimodifikasi dari model Plomp dapat dilihat pada Gambar berikut.

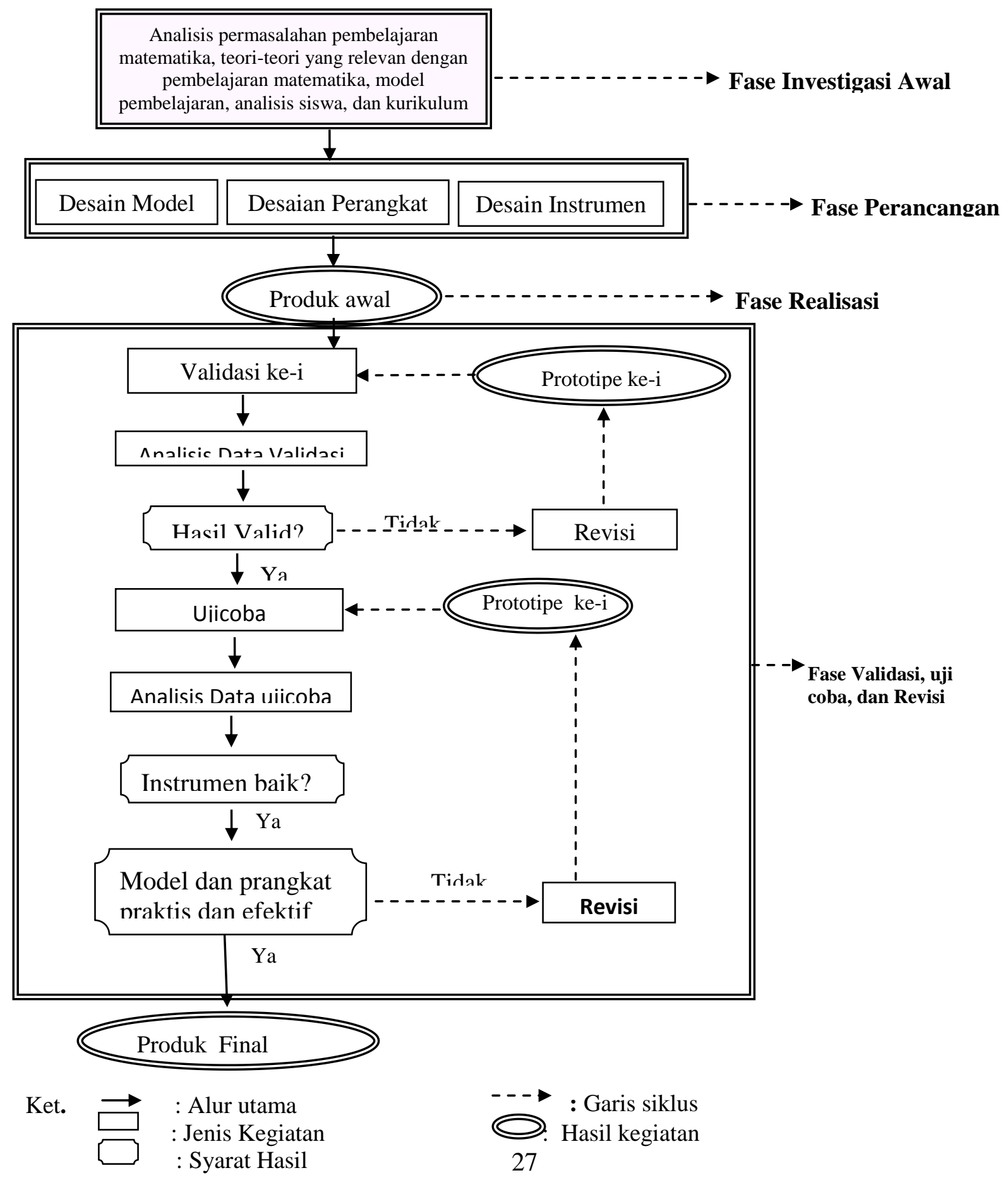




\section{Prosedur Pengembangan}

Model pembelajaran yang digunakan dalam penelitian ini mengacu pada model Plomp yang dimodifikasi. Prosedur pengembangan model pembelajaran dalam penelitian ini terdiri dari empat tahapan, yaitu (1) fase investigasi awal, (2) fase perancangan, (3) fase realisasi, dan (4) fase tes, evaluasi, dan revisi.

\section{Tehnik Analisis Data}

Dalam penelitian ini, terdapat dua teknis dalam analisis data yaitu Analisis Data Kelayakan Seluruh Instrumen dan Analisis Model Pembelajaran Matematika Realistik Indonesia

\section{HASIL PENELITIAN DAN PEMBAHASAN}

Tabel

II

\section{Hasil Analisis Data Kelayakan Instrumen Penelitian}

\begin{tabular}{|c|l|c|c|c|c|c|}
\hline \multirow{2}{*}{ No } & \multirow{2}{*}{ Nama Instrumen } & \multicolumn{2}{c|}{$\begin{array}{c}\text { Hasli penilaian } \\
\text { oleh validator ke- }\end{array}$} & \multicolumn{2}{|c|}{ Frekuensi } & \multirow{2}{*}{ Simpulan } \\
\cline { 3 - 6 } & & 1 & 2 & LD/LDR & TLD & \\
\hline$(1)$ & \multicolumn{1}{|c}{$(2)$} & $(3)$ & $(4)$ & $(6)$ & $(7)$ & $(8)$ \\
\hline 1 & FV isi model & LDR & LDR & 2 & 0 & LDR \\
\hline 2 & FV konstruk model & LD & LD & 2 & 0 & LD \\
\hline 3 & FV RPP & LDR & LDR & 2 & 0 & LDR \\
\hline 4 & FV Buku Siswa & LDR & LDR & 2 & 0 & LDR \\
\hline 5 & FV Buku guru & LDR & LDR & 2 & 0 & LDR \\
\hline 6 & FV LKS & LD & LD & 2 & 0 & LD \\
\hline 7 & FV THB & LD & LD & 2 & 0 & LD \\
\hline 8 & FO Aktivitas siswa dan guru & LD & LD & 2 & 0 & LD \\
\hline 9 & $\begin{array}{l}\text { FO Kemampuan guru } \\
\text { mengelola pembelajaran }\end{array}$ & LD & LD & 2 & 0 & LD \\
\hline 10 & FO Keterlaksanaan model & LD & LD & 2 & 0 & LD \\
\hline 11 & $\begin{array}{l}\text { Angket respons siswa } \\
\text { terhadap model }\end{array}$ & LD & LD & 2 & 0 & LD \\
\hline \multicolumn{2}{|l|}{ Kategori } & & 22 & 0 & \\
\hline
\end{tabular}

Berdasarkan hasil analisis di atas, maka dapat disimpulkan bahwa instrumen penelitian ini layak untuk digunakan dengan beberapa revisi. 
Tabel

III

Hasil Validasi Isi Buku Model

Pembelajaran Matematika Realistik Indonesia

\begin{tabular}{|r|l|c|c|c|c|}
\hline \multirow{2}{*}{ No } & \multicolumn{1}{|c|}{ Komponen } & \multicolumn{3}{c|}{$\begin{array}{c}\text { Rata-Rata Penilaian } \\
\text { Validator Ke- }\end{array}$} & \multirow{2}{*}{$\begin{array}{c}\text { Nilai } \\
\text { Komponen }\end{array}$} \\
\hline & & 1 & 2 & 3 & \\
\hline 1 & Teori pendukung & 4,00 & 4,00 & 4,00 & 4,00 \\
\hline 2 & Sintaks & 4,57 & 4,14 & 4,71 & 4,47 \\
\hline 3 & Sistem social & 4,33 & 3,67 & 4 & 4,00 \\
\hline 4 & Prinsip reaksi & 4,50 & 4,50 & 4,50 & 4,50 \\
\hline 5 & Sistem pendukung & 4,5 & 4 & 5 & 4,50 \\
\hline 6 & Dampak instruksional & 3,86 & 3,71 & 3,86 & 3,81 \\
\hline 7 & Pelaksanaan model pembelajaran & 3,67 & 3,67 & 3,67 & 3,67 \\
\hline \multicolumn{3}{|c|}{ Nilai Rerata Total } & \multicolumn{5}{|c}{4,12} \\
\hline \multicolumn{2}{|c|}{ Kategori } & \multicolumn{5}{|c|}{ Valid } \\
\hline \multicolumn{4}{|c|}{} & \multicolumn{5}{|c|}{} \\
\hline
\end{tabular}

Tabel

IV

Hasil Validasi Konstruk Buku Model

Pembelajaran Matematika Realistik Indonesia

\begin{tabular}{|c|c|c|c|c|c|}
\hline \multirow{2}{*}{$\begin{array}{l}\mathrm{N} \\
\mathrm{o}\end{array}$} & \multirow[t]{2}{*}{ Komponen } & \multicolumn{3}{|c|}{$\begin{array}{l}\text { Rata-rata penilaian } \\
\text { validator ke- }\end{array}$} & \multirow{2}{*}{$\begin{array}{c}\text { Nilai } \\
\text { Kompone } \\
n\end{array}$} \\
\hline & & 1 & 2 & 3 & \\
\hline 1 & $\begin{array}{l}\text { Komponen model } \\
\text { pembelajaran }\end{array}$ & 4,25 & 4,25 & 4,75 & 4,42 \\
\hline 2 & Teori pendukung & 4 & 4 & 4 & 4,00 \\
\hline 3 & Sintaks & 4,50 & 4,17 & 4,83 & 4,50 \\
\hline 4 & Sistem social & 4,50 & 4,25 & 4,50 & 4,42 \\
\hline 5 & Prinsip reaksi & 4,20 & 3,8 & 4 & 4,00 \\
\hline 6 & Sistem pendukung & 4,5 & 4,5 & 4,5 & 4,50 \\
\hline 7 & Dampak instruksional & 4,4 & 4,4 & 4,6 & 4,47 \\
\hline 8 & $\begin{array}{l}\text { Pelaksanaan model } \\
\text { pembelajaran }\end{array}$ & 4 & 4 & 4 & 4,00 \\
\hline & Nilai Rerata Total & \multicolumn{4}{|c|}{4,29} \\
\hline & Kategori & \multicolumn{4}{|c|}{ Sangat Valid } \\
\hline
\end{tabular}

Table

V

Hasil Validasi Perangkat Pembelajaran

\begin{tabular}{|c|c|c|c|c|c|}
\hline \multirow{2}{*}{ No } & $\begin{array}{c}\text { Perangkat } \\
\text { Pembelajaran }\end{array}$ & \multicolumn{3}{|c|}{$\begin{array}{c}\text { Hasil validasi } \\
\text { validator ke- }\end{array}$} & \multirow{2}{*}{$\begin{array}{c}\text { Rata- } \\
\text { rata }\end{array}$} \\
\cline { 3 - 5 } & $\mathbf{1}$ & $\mathbf{2}$ & $\mathbf{3}$ & \\
\hline
\end{tabular}




\begin{tabular}{|c|l|c|c|c|c|}
1 & RPP & 4,15 & 3,92 & 4,08 & 4,15 \\
\hline 2 & Buku Siswa & 4,36 & 4,14 & 4,27 & 4,36 \\
\hline 3 & Buku Guru & 4,07 & 4,26 & 4,3 & 4,07 \\
\hline 4 & LKS & 4,1 & 4,2 & 4,4 & 4,1 \\
\hline 5 & THB & V & V & V & V \\
\hline \multicolumn{2}{|c|}{ Total rata-rata } & \multicolumn{4}{|c|}{$\mathbf{4 , 1 9}$} \\
\hline \multicolumn{2}{|c|}{ Kategori } & \multicolumn{4}{|c|}{ Valid } \\
\hline
\end{tabular}

\section{Table}

VI

Hasil Analisis Data Kepraktisan Model Menurut Ahli/Praktisi

\begin{tabular}{|c|c|c|c|c|c|c|}
\hline \multirow{2}{*}{ No } & $\begin{array}{l}\text { Indikator Penilaian (Item-Item } \\
\text { pada Format Validasi Isi) }\end{array}$ & \multicolumn{3}{|c|}{$\begin{array}{l}\text { Hasil Penilaian Para } \\
\text { Ahli }\end{array}$} & \multirow{2}{*}{$\begin{array}{l}\text { Rata- } \\
\text { rata }\end{array}$} & \multirow{2}{*}{ I-perc } \\
\hline & Isi Pernyataan & 1 & 2 & 3 & & \\
\hline 1 & $\begin{array}{l}\text { Secara teoritis, kemungkinan guru } \\
\text { mampu melaksanakan sintaks } \\
\text { pembelajaran tersebut }\end{array}$ & 5 & 4 & 4 & 4,33 & $\begin{array}{l}\text { Sangat } \\
\text { Tinggi }\end{array}$ \\
\hline 2 & $\begin{array}{l}\text { Secara teoritis, kemungkinan guru } \\
\text { mampu mewujudkan sistem sosial } \\
\text { pembelajaran tersebut }\end{array}$ & 5 & 4 & 4 & 4,33 & $\begin{array}{l}\text { Sangat } \\
\text { Tinggi }\end{array}$ \\
\hline 3 & $\begin{array}{l}\text { Secara teoritis, kemungkinan guru } \\
\text { mampu melaksanakan prinsip reaksi } \\
\text { pengelolaan pembelajaran tersebut }\end{array}$ & 4 & 4 & 3 & 3,67 & Tinggi \\
\hline & Rata-rata Penilaian & 4,67 & 4,00 & 3,67 & 4,11 & Tinggi \\
\hline
\end{tabular}

Tabel

VII

Hasil Analisis Data Keefektifan Model

Menurut Ahli/Praktisi

\begin{tabular}{|c|l|c|c|c|c|}
\hline \multirow{2}{*}{$\begin{array}{c}\mathrm{N} \\
\mathrm{o}\end{array}$} & \multicolumn{1}{|c|}{$\begin{array}{c}\text { Indikator Penilaian (item-item pada } \\
\text { format validasi Isi) }\end{array}$} & \multicolumn{2}{|c|}{$\begin{array}{c}\text { Hasil Penilaian } \\
\text { Para }\end{array}$} & \multirow{2}{*}{$\begin{array}{c}\text { Rata } \\
\text {-rata }\end{array}$} \\
\cline { 2 - 5 } 1 & \multicolumn{1}{|c|}{ Isi Pernyataan } & 1 & 2 & 3 & \\
\hline 1 & $\begin{array}{l}\text { Tercapainya tujuan pembelajaran yang } \\
\text { dirumuskan dalam bentuk kompetensi } \\
\text { dasar }\end{array}$ & 4 & 4 & 4 & 4,00 \\
\hline 2 & $\begin{array}{l}\text { Respons siswa yang positif terhadap } \\
\text { model pembelajaran matematika } \\
\text { realistik Indonesia }\end{array}$ & 4 & 4 & 4 & 4,00 \\
\hline 3 & $\begin{array}{l}\text { Tercapainya waktu ideal untuk aktivitas } \\
\text { matematisasi siswa }\end{array}$ & 3 & 3 & 3 & 3,00 \\
\hline 4 & $\begin{array}{l}\text { Secara teoritis kemungkinan guru } \\
\text { mampu untuk melaksanakan sintaks } \\
\text { pembelajaran tersebut }\end{array}$ & 5 & 4 & 4 & 4,33 \\
\hline 5 & Secara teoritis kemungkinan guru & 4 & 4 & 3 & 3,67 \\
\hline
\end{tabular}




\begin{tabular}{|c|c|c|c|c|c|}
\hline & $\begin{array}{l}\text { mampu untuk melaksanakan sistem } \\
\text { sosial pembelajaran tersebut }\end{array}$ & & & & \\
\hline 6 & $\begin{array}{l}\text { Kemungkinan guru dapat melaksanakan } \\
\text { prinsip reaksi pengelolaan pembelajaran } \\
\text { tersebut }\end{array}$ & 5 & 4 & 4 & 4,33 \\
\hline & Rata-rata Penilaian & $\begin{array}{r}4,1 \\
7\end{array}$ & $\begin{array}{r}3,8 \\
3\end{array}$ & $\begin{array}{r}3,6 \\
7\end{array}$ & 3,89 \\
\hline & Tingkat Keefektifan & \multicolumn{4}{|c|}{ Tinggi } \\
\hline
\end{tabular}

Tabel

VIII

Hasil Analisis Data

Kemampuan Guru Mengelola Pembelajaran

\begin{tabular}{|c|c|c|c|c|c|c|c|}
\hline \multirow[t]{2}{*}{ No } & \multirow[t]{2}{*}{ Aspek yang Dinilai } & \multicolumn{4}{|c|}{$\begin{array}{c}\text { Rata-rata Penilaian } \\
\text { Setiap Pertemuan ke- }\end{array}$} & \multirow{2}{*}{$\begin{array}{l}\text { Rata- } \\
\text { rata }\end{array}$} & \multirow[t]{2}{*}{ Kategori } \\
\hline & & $\mathrm{I}$ & II & III & IV & & \\
\hline 1 & $\begin{array}{l}\text { Memberikan masalah } \\
\text { kontekstual }\end{array}$ & 3,67 & 3,83 & 3,83 & 4,00 & 3,83 & Baik \\
\hline 2 & $\begin{array}{l}\text { Mendiskripsikan } \\
\text { masalah kontekstual }\end{array}$ & 3,25 & 3,50 & 3,50 & 4,00 & 3,56 & Baik \\
\hline 3 & $\begin{array}{l}\text { Menyelesaikan } \\
\text { masalah kontekstual }\end{array}$ & 3,25 & 4,00 & 3,50 & 3,25 & 3,50 & Baik \\
\hline 4 & $\begin{array}{l}\text { Membandingkan dan } \\
\text { mendiskusikan } \\
\text { jawaban }\end{array}$ & 3,60 & 3,90 & 3,70 & 3,80 & 3,75 & Baik \\
\hline 5 & Menarik Kesimpulan & 3,00 & 3,33 & 3,25 & 3,33 & 3,23 & Cukup \\
\hline 6 & $\begin{array}{l}\text { Kemampuan } \\
\text { Mengelola Waktu: }\end{array}$ & 2,50 & 2,50 & 2,50 & 4,00 & 2,88 & Cukup \\
\hline 7 & Suasana Kelas & 4,00 & 4,00 & 4,00 & 4,00 & 4,00 & Baik \\
\hline \multicolumn{6}{|c|}{ Total Rata-rata } & \multicolumn{2}{|c|}{3,54} \\
\hline \multicolumn{6}{|c|}{ Kategori Nilai Kemampuan Guru } & \multicolumn{2}{|c|}{ Baik } \\
\hline
\end{tabular}

Tabel

IX

Hasil Analisis Data Aktivitas Siswa

\begin{tabular}{|l|l|c|c|}
\hline \multicolumn{1}{|c|}{ Kategori Pengamatan } & Persentase & \multicolumn{1}{|c|}{$\begin{array}{c}\text { Waktu } \\
\text { Ideal }\end{array}$} & $\begin{array}{c}\text { Batas } \\
\text { Toleransi } \\
\text { waktu Ideal }\end{array}$ \\
\hline $\begin{array}{l}\text { 1. Mendengarkan/memperhatikan penjelasan guru } \\
\text { dengan aktif }\end{array}$ & 15,36 & $20 \%$ & $\begin{array}{c}15 \%-25 \\
\%\end{array}$ \\
\hline 2. Membaca/memahami soal/masalah & 8,07 & $5 \%$ & $0 \%-10 \%$ \\
\hline $\begin{array}{l}\text { 3. Menjawab pertanyaan guru atau bertanya kepada } \\
\text { guru }\end{array}$ & 10,42 & $5 \%$ & $0 \%-10 \%$ \\
\hline 4. Mendeskripsikan dan menyelesaikan soal/masalah & 27,34 & $32 \%$ & $\begin{array}{c}27 \%-37 \\
\%\end{array}$ \\
\hline 5. Membandingkan jawaban dan berdiskusi dalam & 9,64 & $7 \%$ & $2 \%-12 \%$ \\
\hline
\end{tabular}




\begin{tabular}{|l|l|c|c|}
\hline kelompok belajar & & & \\
\hline 6. Mempresentasikan/menyampaikan jawaban & 4,69 & $3 \%$ & $0 \%-8 \%$ \\
\hline $\begin{array}{l}\text { 7. Memperhatikan teman mempresentasikan jawaban } \\
\text { dengan aktif }\end{array}$ & 13,54 & $15 \%$ & $\begin{array}{c}10 \%-20 \\
\%\end{array}$ \\
\hline $\begin{array}{l}\text { 8. Menanggapi jawaban teman atau menyampaikan } \\
\text { pendapat/ide/gagasan kepada guru }\end{array}$ & 3,91 & $3 \%$ & $0 \%-8 \%$ \\
\hline 9. Menulis kesimpulan/rangkuman di buku catatan & 6,77 & $10 \%$ & $5 \%-15 \%$ \\
\hline $\begin{array}{l}\text { 10. Aktivitas yang tidak relevan dengan kegiatan } \\
\text { pembelajaran (seperti: melamun, berjalan-jalan di } \\
\text { luar kelompok belajarnya, membaca } \\
\text { buku/mengerjakan tugas mata pelajaran lain, } \\
\text { bermain-main dengan teman dan lain-lain). }\end{array}$ & 0,26 & $0 \%$ & $0 \%-5 \%$ \\
\hline
\end{tabular}

\section{Table}

\section{$\mathbf{X}$}

Hasil Analisis Data Respons Siswa

\begin{tabular}{|c|c|c|c|c|c|c|}
\hline \multirow{2}{*}{ No } & \multirow{2}{*}{ Aspek yang direspons } & \multicolumn{2}{|c|}{ Respons Siswa } & \multicolumn{2}{|c|}{ Persentasi } & \multirow{2}{*}{ Kategori } \\
\hline & & senang & tidak & senang & tidak & \\
\hline 1 & $\begin{array}{l}\text { Perasaan siswa terhadap komponen } \\
\text { pembelajaran }\end{array}$ & & & & & \\
\hline & Materi Pelajaran & 34 & 1 & 94.44 & 2.78 & Positif \\
\hline & Buku Siswa & 30 & 5 & 83.33 & 13.89 & Positif \\
\hline & LKS & 35 & 0 & 97.22 & 0.00 & Positif \\
\hline & Lembar Soal Tes Hasil Belajar & 34 & 1 & 94.44 & 2.78 & Positif \\
\hline & Suasana Pembelajaran di kelas & 32 & 3 & 88.89 & 8.33 & Positif \\
\hline & Cara guru mengajar & 35 & 0 & 97.22 & 0.00 & Positif \\
\hline \multirow{2}{*}{\multicolumn{2}{|c|}{ Rata-rata Persentase }} & & & 92.59 & 4.63 & Positif \\
\hline & & Baru & Tidak & Baru & Tidak & \\
\hline \multirow[t]{7}{*}{2} & $\begin{array}{l}\text { Pendapat siswa tentang komponen } \\
\text { pembelajaran }\end{array}$ & & & & & \\
\hline & Materi Pelajaran & 29 & 6 & 82.86 & 17.14 & Positif \\
\hline & Buku Siswa & 32 & 3 & 91.43 & 8.57 & Positif \\
\hline & LKS & 32 & 3 & 91.43 & 8.57 & Positif \\
\hline & Lembar Soal Tes Hasil Belajar & 33 & 2 & 94.29 & 5.71 & Positif \\
\hline & Suasana Pembelajaran di kelas & 34 & 1 & 97.14 & 2.86 & Positif \\
\hline & Cara guru mengajar & 34 & 1 & 97.14 & 2.86 & Positif \\
\hline \multicolumn{2}{|r|}{ Rata-rata Persentase } & & & 92.38 & 7.62 & \\
\hline & & Berminat & Tidak & Berminat & Tidak & \\
\hline \multirow[t]{2}{*}{3} & $\begin{array}{l}\text { Pendapat siswa untuk mengikuti pembelajaran } \\
\text { selanjutnya, seperti yang diikuti }\end{array}$ & 35 & 0 & 100.00 & 0.00 & Positif \\
\hline & & Jelas & Tidak & Jelas & Tidak & \\
\hline \multirow[t]{4}{*}{4} & $\begin{array}{l}\text { Pendapat siswa mengenai bahasa yang } \\
\text { digunakan dalam: }\end{array}$ & & & & & \\
\hline & Buku Siswa & 29 & 6 & 82.86 & 17.14 & Positif \\
\hline & LKS & 30 & 5 & 85.71 & 14.29 & Positif \\
\hline & Lembar Soal Tes Hasil Belajar & 34 & 1 & 97.14 & 2.86 & Positif \\
\hline \multirow{2}{*}{\multicolumn{2}{|c|}{ Rata-rata Persentase }} & & & 88.57 & 11.43 & Positif \\
\hline & & Mengerti & Tidak & Mengerti & Tidak & \\
\hline \multirow[t]{4}{*}{5} & $\begin{array}{l}\text { Pendapat siswa mengenai maksud dari setiap } \\
\text { soal/ masalah yang disajikan dalam: }\end{array}$ & & & & & \\
\hline & Buku Siswa & 30 & 5 & 85.71 & 14.29 & Positif \\
\hline & LKS & 33 & 2 & 94.29 & 5.71 & Positif \\
\hline & Lembar Soal Tes Hasil Belajar & 31 & 4 & 88.57 & 11.43 & Positif \\
\hline \multirow{2}{*}{\multicolumn{2}{|c|}{ Rata-rata Persentase }} & & & 89.52 & 10.48 & Positif \\
\hline & & Tertarik & Tidak & Tertarik & Tidak & \\
\hline 6 & $\begin{array}{l}\text { Pendapat siswa tentang penampilan (tulisan, } \\
\text { ilustrasi/gambar dan letak gambar), yang }\end{array}$ & & & & & \\
\hline
\end{tabular}




\begin{tabular}{|c|c|c|c|c|c|}
\hline \multicolumn{6}{|l|}{ terdapat dalam: } \\
\hline Buku Siswa & 33 & 2 & 94.29 & 5.71 & Positif \\
\hline LKS & 34 & 1 & 97.14 & 2.86 & Positif \\
\hline Lembar Soal Tes Hasil Belajar & 33 & 2 & 94.29 & 5.71 & Positif \\
\hline Rata-rata Persentase & & & 95.24 & 4.76 & Positif \\
\hline
\end{tabular}

Table

XI

Data Hasil Belajar Siswa

\begin{tabular}{|c|c|c|}
\hline No. Urut Siswa & SKOR & Tingkat Hasil Belajar Siswa \\
\hline (1) & (2) & (3) \\
\hline 1 & 41 & SANGAT TINGGI \\
\hline 2 & 30,5 & TINGGI \\
\hline 3 & 34 & TINGGI \\
\hline 4 & 33 & TINGGI \\
\hline 5 & 41 & SANGAT TINGGI \\
\hline 6 & 24,5 & SEDANG \\
\hline 7 & 34 & TINGGI \\
\hline 8 & 22,5 & SEDANG \\
\hline 9 & 39 & SANGAT TINGGI \\
\hline 10 & 39,5 & SANGAT TINGGI \\
\hline 11 & 38,5 & TINGGI \\
\hline 12 & 45 & SANGAT TINGGI \\
\hline 13 & 37 & TINGGI \\
\hline 14 & 29,5 & TINGGI \\
\hline 15 & 24 & SEDANG \\
\hline 16 & 34 & TINGGI \\
\hline 17 & 37 & TINGGI \\
\hline 18 & 34,5 & TINGGI \\
\hline 19 & 32 & TINGGI \\
\hline 20 & 38,5 & TINGGI \\
\hline 21 & 30 & TINGGI \\
\hline 22 & 40 & SANGAT TINGGI \\
\hline 23 & 25,5 & SEDANG \\
\hline 24 & 34,5 & TINGGI \\
\hline 25 & 23,5 & SANGAT TINGGI \\
\hline 26 & 35,5 & TINGGI \\
\hline 27 & 38,5 & TINGGI \\
\hline 28 & 43,5 & TINGGI \\
\hline 29 & 23 & SANGAT TINGGI \\
\hline 30 & 32 & SEDANG \\
\hline 31 & 45,5 & TINGGI \\
\hline 32 & 36 & SEDANG \\
\hline 33 & 28,5 & SANGAT TINGGI \\
\hline 34 & 35,5 & SANGAT TINGGI \\
\hline 35 & 47,5 & TINGGI \\
\hline \multicolumn{2}{|c|}{$\begin{array}{l}\text { Persentasi siswa yang mencapai } \\
\text { tingkat hasil belajar tinggi dan } \\
\text { sangat tinggi }\end{array}$} & $80 \%$ \\
\hline
\end{tabular}

\section{Kesimpulan}

Berdasarkan pertanyaan penelitian dan hasil penelitian yang telah diuraikan, diperoleh kesimpulan sebagai berikut. Pertama, Dihasilkan Model Pembelajaran Matematika Realistik Indonesia tentang perbandingan yang memenuhi kriteria valid, praktis, dan efektif. Kedua, Dihasilkan perangkat pembelajaran sebagai 
pendukung penerapan Model Pembelajaran Matematika Realistik Indonesia dalam materi Perbandingan. Perangkat pembelajaran tersebut adalah: (1) Rencana Pelaksanaan Pembelajaran (RPP), Buku Siswa (BS), Buku Guru (BG), Lembar kegiatan Siswa (LKS), dan Tes Hasil Belajar (THB). Perangkat-perangkat tersebut memenuhi kriteria valid dan hasil uji coba menunjukkan bahwa perangkat pembelajaran tersebut dapat mendukung penerapan model pembelajaran terlaksana secara praktis dan efektif .

Ketiga, Tingkat kevalidan Model Pembelajaran Matematika Realistik Indonesia beserta seluruh perangkat pembelajaran yang digunakan termasuk kategori valid. Keempat, Tingkat kepraktisan Model Pembelajaran Matematika Realistik Indonesia beserta seluruh perangkat pembelajaran yang digunakan dalam pelaksanaan pembelajaran di kelas termasuk kategori sedang. Kelima, Ketercapaian keefektifan Model Pembelajaran Matematika Realistik disimpulkan berdasarkan pada; (1) persentase banyak siswa yang memiliki tingkat penguasaan minimal tinggi dan sangat tinggi adalah $80 \%$ dari 35 siswa yang mengikuti tes. Persentase ini menunjukkan dari ketercapaian ketuntasan belajar siswa secara klasikal. (2) persentasi waktu ideal untuk setiap kategori aktivitas siswa dan guru sudah dipenuhi, (3) rata-rata nilai kategori guru kemampuan guru mengelola pembelajaran adalah 3,54 termasuk dalam kategori baik, (4) respons siswa terhadap komponen dan kegiatan pembelajaran adalah positif.

\section{Daftar Pustaka}

Allen, M. J. \& Yen, W. M. (1979). Introduction to measurement theory. Monterey, CA: Brooks/Cole Publishing Company.

Gravemeijer, K. P. E. (1994). Developing realistics mathematics education. Utrecht: CD $\beta$ Press.

Joyce, \& Weil, M. (1992). Model of teaching ( $4^{\text {th }} e d$ ). Boston: Allyn and Bacon.

Kemp, J. E. Morrison, G. R. \& Ross, S. M. (1994). Designing effective instruction. New York: Macmillan College Publishing Company. 
Masykur, Moch. \& Halim Fathani, Abdul. (2007). Mathematical intelligence cara cerdas melatih otak dan menanggulangi kesulitan belajar. Yogyakarta: Arruzz Media.

Nieveen, N. (1999). Prototyping to reach product quality. Enschede: University of Twente.

Nur, M. \& Wikandari, P. R. (2000). Pengajaran berpusat kepada siswa dan pendekatan konstrukstivis dalam pengajaran. Edisi ke-3. Surabaya: Pusat Studi Matematika dan IPA Sekolah.

Plomp, T. (2001). Design methodology and developmental research in/on education and training. faculty of Education Science and Technology (FEST) University of Twente Enschede: TP.

Soedjadi, R. (2000). Kiat pendidikan matematika Indonesia. Jakarta: Direktorat Jendral Pendidikan Tinggi Departemen Pendidikan Nasional.

Sri Wulandari Danoebroto. (2007). Pengaruh pembelajaran matematika dengan pendekatan pendidikan matematika realistik indonesia dan pelatihan metakognitif terhadap kemampuan pemecahan masalah siswa sekolah dasar. Tesis Magister, tidak diterbitkan, Universitas Negeri Yogyakarta, Yogyakarta.

Suryanto. \& Sugiman. (2006). Metode pembelajaran dimulai dengan pengenalan situasi riil. Diambil pada tanggal 16 Oktober 2006, dari http://www.kompas.com/kompas-cetak/0610/16jogja/29886.htm.

Suryanto. (Juni 2000). Pendekatan Realistik: Suatu Inovasi Pembelajaran Matematika. Cakrawala Pendidikan, Th. XIX No. 3, 109- 115.

Van den Heuvel - Panhuizen, M. (1996). Assesment and realistic mathematics education. Utrecht: Freudental Institut. 